Terbit online pada laman web jurnal : http://teknosi.fti.unand.ac.id/

Jurnal Nasional Teknologi dan Sistem Informasi

ISSN (Print) 2460-3465 | ISSN (Online) 2476-8812

Artikel Penelitian

\title{
User Behavior in Adopt Mobile Commerce (Scale Development: Perspective of Trust and Risk)
}

\author{
Setiawan Assegaff, Jasmir ${ }^{a}$, Dodo Zaenal Abidin ${ }^{a}$, Sharipuddin ${ }^{a}$
}

${ }^{a}$ STIKOM Dinamika Bangsa, Jl. Jend. Sudirman, Thehok, Jambi, 36138, Indonesia

\begin{tabular}{|c|}
\hline INFORMASI ARTIKEL \\
\hline $\begin{array}{l}\text { Sejarah Artikel: } \\
\text { Diterima Redaksi: } 21 \text { Agustus } 2017 \\
\text { Revisi Akhir: } 17 \text { Desember } 2017 \\
\text { Diterbitkan Online: } 31 \text { Desember } 2017\end{array}$ \\
\hline KATA KUNCI \\
\hline User Behavior; \\
\hline Mobile Commerce; \\
\hline Trust; Risk \\
\hline KORESPONDENSI \\
\hline Telepon: $+62(741) 35095$ \\
\hline E-mail: setiawanassegaff@stikom-db.ac.id \\
\hline
\end{tabular}

\section{A B S T R A C T}

The purpose of ours study is to explore the relation between the elements of trust and risk and their impact on consumer behavior in the intention of use of mobile commerce services based on sales. The final objective of this study is to recognize consumer behavior in the use of mobile commerce application services in Indonesia by considering the elements of trust and risk in consumer behavior. Finding from previous research have revealed that trust and risk is one of the critical aspects in the use of e-commerce services. This research focus is to explain the development stages of research instruments development to be used in next survey agenda. By applying Technology Acceptance Model (TAM) as a theoretical basis of a conceptual model and the research instrument was developed. Models and instruments then validated through a pilot study involving 75 students as respondents. Survey data were analyzed via Smart-PLS software version 2 to ensure reliability level and validity of the instrument. This study resulted in a validated instrument that will be used to collect data from actual surveys

\section{INTRODUCTION}

In this decade, the use of internet technology has entered nearly all aspects of human life activities, particularly in the business world [1]. This phenomenon has brought the opportunity for the organization in make a significant impact on the progress of global business activities in various countries [2,3]. The use of Internet technology can be claimed as one of the innovative ways that could help companies in improving their business performance in the market [4]. Utilizing information technology that makes the company's business feasible to do virtual business activity in is known as E-commerce. Scholars and Companies Managers belief that electronic business activities (e-business / ecommerce) have brought their business processes to be simplified and give benefit to the seller or the buyer [5]. For the sellers, ecommerce will benefit to enlarge the promotion capacity of the product that will be traded, while for the customer, will make it at ease to find and compare data about the product to be bought. Through the utilization of information technology and the Internet, organizations can conduct various business activities virtually for example; transaction ordering goods, sales of goods, and purchasing goods online. In addition, the company can also carry out other business functions such as sharing data with clients and dealers to keep and build interactions before, during and after the commerce process done [5].

Nowadays, E-commerce is applied through most in all various methods and electronic devices [6]. In Indonesia the participation of people and companies participate and develop their business through e-commerce has shown significant growth [7]. Utilization of mobile technologies in e-commerce activities was obtained a good response from consumers in Indonesia, it is proved by the increasing number of e-commerce transactions consumer through their smartphones. One of the e-commerce service providers that based on mobile which is currently received very widespread in public is called Traveloka Company. The company provides services such as the provision of services for hotel vouchers and electronic tickets for airlines. Although the Traveloka Company has got a good response from the community, but if the number of participants is compared by the all potential participant in Indonesia, so the participant rate for mobile commerce use is relative low.

Attribution-NonCommercial 4.0 International. Some rights reserved 
Online ticketing is one for Traveloka feature services that offer for customers. These services became popular because it took away some barriers customer face in manual ticketing, the advantages came from online ticketing such as availability of competitive ticket price information, complete information related to the flight schedule and etc. Air company tickets are the greatest traded item for consumption on the Internet in Spain, amounting to $36.5 \%$ of electronic commerce. In the US, airline websites have also grown as a mechanism for selling airline tickets, capturing $58 \%$ of sales in 2005 [8]. In Indonesia, there is a fact that online ticketing services have growth rapidly. This brings opportunity for Indonesia to encourage more transaction in online services.

To rise the quantity of users who participate in the mobile commerce services, the companies like Traveloka need to build the understand user perception in e-commerce and able to predict the customer behavior and consumer perception towards their mobile commerce services. Based on previous research one aspect that greatly influences customers to adopt mobile commerce services is trust and risk [9]. That's why in this study we are interested in the topic of how the elements of trust and risk influence on consumer behavior that is using mobile services.

This article organized with the following designed; the first part of this article talk over the concepts, theories from previous studies that are relevant to this topic. Then it will be discuss the methodology used in solving the problem of the research, the next part is a presentation related with the development and validation of models and research instruments and final part will be a discussion of study finding. This article will be closed with the conclusion

\section{RESEARCH METHOD}

There are some stages to develop instrument for Information System research. First is develop a research model, next stage is defining a relationship between variable in research model. Third stage is defining operational definition of each variable that include in research model. The fourth stage is developing indicator use to measure each variable in research model. The final stage is validating instrument.

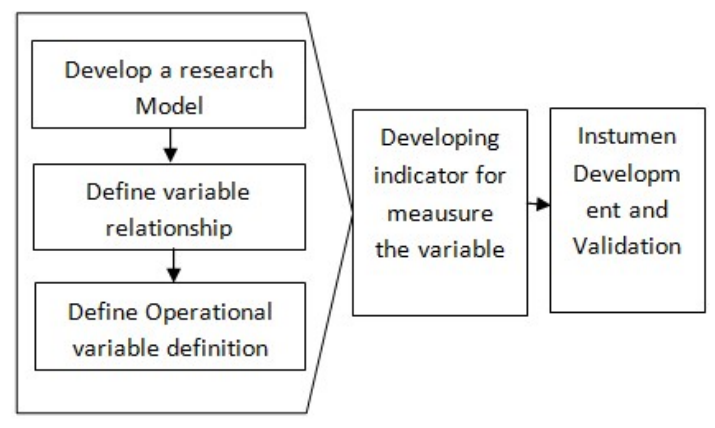

Figure 1. Research Stage

\section{RESULTS AND DISCUSSION}

\subsection{Research Model Development}

The research model was developing base on Technology Acceptance Model (TAM) by Davis [10]. TAM was developing

321 Setiawan Assegaff base on Theory Reason of action (TRA). TRA is a theory state that people will decide to take an action depend on his/her reaction and perception for that action. Reaction and perception of people on a technology would influence his/her behavior.

TAM recognize as most popular theory that apply to understand people behavior in adopt a technology. TAM has two main determinants in understand people behavior known as Perceive Usefulness and Perceived Ease of Use.

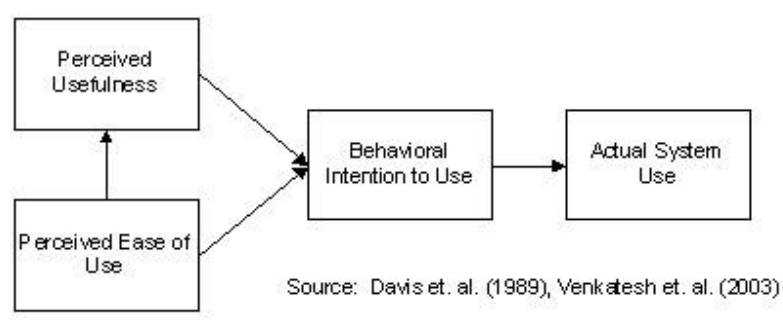

Figure 2. Technology Acceptance Model (Davis, 1989)

Perceived Usefulness determinant was define as people perception that using a technology would bring benefit for them. By using the technology his/ her job performance will increase. Perceived Ease of Use is people perception that using a technology would take less effort.

Previous research conducted by applying TAM found that Perceived Usefulness and Perceived Ease of Use were the most important determinant that influences people in decides their decision in adopts or not adopt a technology.

However, in mobile commerce context, there are another factors that people should consider when they intent to adopt the technology. Research in e-commerce as well as mobile commerce suggests trust and risk factor as two critical elements. Previous research conducted to explore how trust and risk are influence people behavior in adopt mobile commerce such as [11-14]

\section{Trust}

There is some different definition related with trust found in literature. However, in general trust is define as notion of confident, belief, expectation, dependence, and reliance on the goodness, reliability, integrity, ability and or character for one entity [15]. Trust in mobile commerce adoption is related with people/ customer belief that their mobile application will meet their expectation [15]

Trust has been recognising as customer fundamental foundation to adopt mobile commerce services. In fact, mobile commerce services provider would not get customer trust easily. In develop people trust, e-commerce provider need to maintenance good communication and relationship with their customers. The progress is important in order to keep their trust.

Mukherjee and Nath (2003) in their article propose a mechanism in how trusts develop among customer in banking sector. In their study they reveal that bank as well as customer is important to share same value in their relationship. Another research in this area also found that trust as important element for customer in adopts electronic services. [16-20]

\section{Risk Factor}

Since 1960 risk element has been studied to understand it relationship with human behaviour. Previous study also explore

https://doi.org/10.25077/ TEKNOSI.v3i3.2017.320-325 
how risk effect people decision. Peter and Ryan [21] defines risk as some kind of loss occur when people decide to take an action. Another definition by Featherman dan Palvou [22] state that risk as people perception in possible loss granted if they try to achieve a goal. Lee [23] in his study propose some indicator related with risk elements such as security, financial, Social, Time.

\section{Relationship between Trust, Risk and Intention to Use}

Based on previous studies we have propose tow relationship between trust, risk, and behavior element

\section{Independent relationship}

Researchers in Information system interested to understand relationship between trust, risk and behavior element [24]. Many studies has explore to understand their relationship.

Kim dan Prabhabkar [25] conduct studies to understand how trust and risk impact people behavior in using information system. In their research they propose that trust and risk element is not depending each other but they will impact people behavior independently.

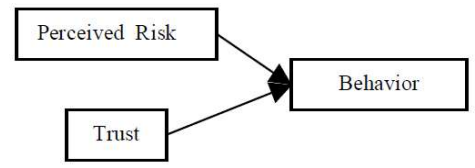

Figure 3. Relationship between Trust, Risk and People Behavior (Independent Relationship)

2. Mediation Relationship

Another concept related with how trust and risk impact people behavior was propose by Jarvenpaa [26]. He argues that both element trust and risk has relation as moderation. Trust will impact risk and risk will influence people behavior.

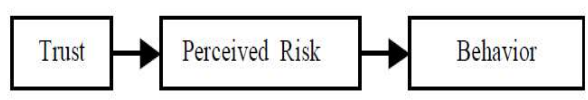

Figure 4. Relationship between Trust, Risk and People Behavior (Mediation Relationship)

In this research, we interested to conduct study with explore trust and risk impact to people behavior when using mobile commerce services. We apply concept by Jarvenpaa [26] that argue trust and risk has mediation relationship when influences people behavior. Our research model describes bellow:

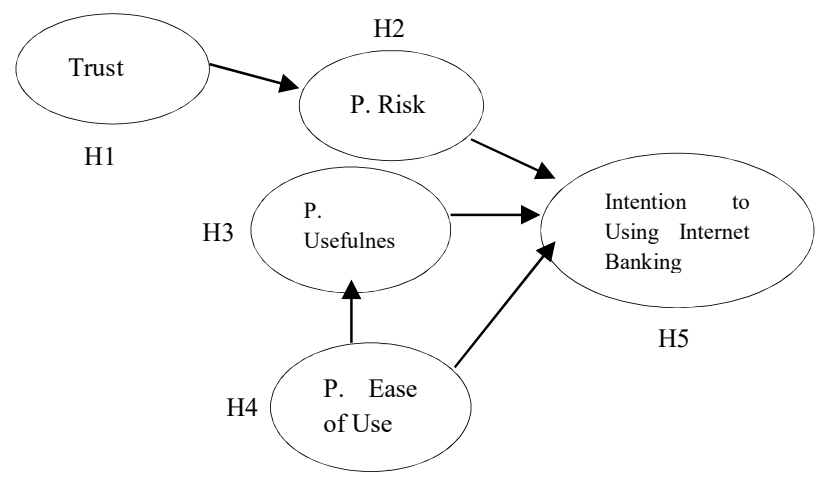

Figure 5. Research Model

\subsection{Development of Hypotheses}

The next demonstrate the association between variables in this research. In this research, there are three independent variables, the variable "trust", "perceived usefulness" and "perceived ease of use". In our propose model also has two dependent variables is the "risk" and "intention to use mobile commerce"

Hypothesis that is built are:

H1: Trust positively influences risk the use of mobile commerce

H2: Perceived Risk positively influences the intention of use the mobile commerce.

H3: Perceived Usefulness positively influence the intention of use the mobile commerce

H4: Perceived Ease of Use positively influence Perceive of Usefulness uses the mobile commerce

H5: Perceived Ease of Use positively influences the intention of use the mobile commerce

Table 1 Definition of Variables in Research

\begin{tabular}{|c|c|c|}
\hline Variable & Definition & References \\
\hline Trust & $\begin{array}{l}\text { Notion from confident, belief, } \\
\text { expectation, dependence, and } \\
\text { reliance on the goodness, reliability, } \\
\text { integrity, ability know the character } \\
\text { of the Mobile Commerce service }\end{array}$ & {$[20]$} \\
\hline Risk & $\begin{array}{l}\text { Possible of losses incurred by } \\
\text { consumers when using the services } \\
\text { of Mobile Commerce. }\end{array}$ & {$[27]$} \\
\hline $\begin{array}{l}\text { Perceived } \\
\text { Usefulness }\end{array}$ & $\begin{array}{l}\text { Direct and indirect benefits expected } \\
\text { from the use of Mobile Commerce }\end{array}$ & {$[28]$} \\
\hline $\begin{array}{l}\text { Perceived Ease } \\
\text { of Use }\end{array}$ & $\begin{array}{l}\text { It is associated with the effort that is } \\
\text { borne by the consumer when using } \\
\text { mobile commerce services. The } \\
\text { smaller the effort required by } \\
\text { customers are likely to encourage } \\
\text { consumers to use this service }\end{array}$ & [28] \\
\hline Intention & It is associated with consumer & [28] \\
\hline Use Mobile & intentions in using the service. & \\
\hline Commerce & $\begin{array}{l}\text { Researchers agree that the intention } \\
\text { would describe the behavior of a } \\
\text { consumer. So if the consumer intends } \\
\text { to use this service in the future it is } \\
\text { likely consumers will use the service. }\end{array}$ & \\
\hline
\end{tabular}

Table 2 Variable and indicators

\begin{tabular}{|c|c|c|}
\hline Variable & $\begin{array}{ll}\text { Number } & \text { of } \\
\text { Indicators } & \end{array}$ & References \\
\hline Trust & 9 Indicators & [20] \\
\hline Risk & 11 indicators & [29] \\
\hline $\begin{array}{l}\text { Perceived } \\
\text { Fullness }\end{array}$ & 3 Indicators & [28] \\
\hline Perceived Ease of Use & 3 Indicators & [28] \\
\hline $\begin{array}{l}\text { Intention to Use } \\
\text { Mobile Commerce }\end{array}$ & 3 Indicators & [29] \\
\hline
\end{tabular}




\subsection{Evaluate the instrument}

The steps of the evaluation of the instrument are over a series of statistical assessment. This step goal is certify that the research instrument established in this research in line with the standards that have been resolute in a quantitative research. In quantitative study, the validity and reliability of a research instrument are a process that essential be conducted.

In conducted evaluation of instrument, the instrument was distributed to respondent. The data collection was done by direct distribution to the respondent. For these evaluation activities total of 30 of the questions submitted in this questionnaire. Questionnaires were circulated to students at STIKOM Dinamika Bangsa. Total of 75 respondents responded to the questionnaire which is declared as valid.

Assessment of instrument is a most important process that must be conducted before the evaluation of hypotheses. This step goal is to grantees that the research instrument established in this research has standard that have been gritty in a quantitative research. In quantitative research, the validity and reliabilities to a research instrument are a process that essential to be conducted.

\section{A. Reliability Test}

Reliability mean as the grade of reliable of an instrument, whether the instrument will provide constant outcomes when fill by different respondents. To evaluate the reliability of the estimation of the value of alpha compositing reliability and Cronbach some of the variables exist in the instrument of study proposed. Cronbach alpha rate is exceeding 0.7 shows the grades of the reliability is worthy for a variable. In the table below we can see that all the variables are at a value above 0.7 . This confirms that the grade of reliability of variables in terms of the value of alpha is Cronbach meets the standard. Value composite reliability is good is if it is above 0.7 . In the table below can be reveals that all grades of each variable $\mathrm{CR}$ are above 0.8 , it illustrates that all variables have met the standard and meet the variable of reliability.

Table 3 Reliability Test Results

\begin{tabular}{|c|c|c|}
\hline Variable & $\begin{array}{ll}\begin{array}{l}\text { Number } \\
\text { Indicators }\end{array} & \text { of } \\
\end{array}$ & $\begin{array}{l}\text { Composite } \\
\text { Reliability } \\
\end{array}$ \\
\hline EASE OF USE & 3 & 0.892 \\
\hline INTENTION TO USE & 3 & 0.8967 \\
\hline RISK & 11 & 0.9343 \\
\hline TRUST & 9 & 0.9269 \\
\hline USEFULNESS & 3 & 0.9315 \\
\hline
\end{tabular}

One more element that can be apply as a supplementary orientation in evaluate the reliability is the grades of each variable AVE. AVE grades above 0.5 is reflected to have met the standard. From the table above it can be summarized that the lowermost grades for each variable AVE is 12:58 preserved by the variable "Trust" (see Table 6.5), we can summarized that all variables have to had the criteria of reliability that have been valid.

\section{B. Validity Test}

Research an instrument is qualified as respectable if it has validity that standard on criteria. So that when the instrument is applying for assessment the function, it will deliver outcomes in accordance with the goals for which such measurements. While assessments have small validity will probable create fewer data or may not match to goal of measurement.

In conducted the validity of the assessment, it can be conducted out an assessment of the "construct validity". Assessment of "construct validity" is to evaluate the extent to which the test is projected to quantity a theoretical construct. The test was conducted with two main steps: first, the constructor asses conducted with factor analysis step. Second, consider how the association qualities that describe the other variables, in this case, will apply assessment to be done with concerns to "construct validity" is a test "discriminant validity" and "convergent validity".

\section{(i) Analysis of Factors}

Factor analysis is appropriate important for the validation of the contact because it can be apply to recognise and admittance the relative power of the various characteristics of different psychological qualities. Factor analysis can also be applied in planning assessment to recognise the factor or factors primer through a series of different tests. Thus, factor analysis can be used to shorten an evaluation or other by decreasing the amount of types into an amount of factors or some typical trait alone

\section{(ii) Convergent Validity}

One of technique could apply to attain the "construct validity" is to running a assessment correlation or convergence of the existing variable with the indicator. Indicator variables that converge or correlated with other indicators in a variable that is theoretically similar to it. The value of loading factors shows all of indictors meet minimum criteria for data analysis. The lowest value is indicators "RS" the value 0,6148 .

\section{(iii) Discriminant Validity}

The evaluation has to not only determine the validity of this convergence but include require the discriminatory validity, which would specify little or negatively association with variables that are theoretically dissimilar. Thus, scores on tests of reading comprehension test should show a positive correlation with the performance in language lessons and a negative correlation with the performance in arithmetic. The scores of cross loading factors indicate that all of the indicators is associate with it group and meet the minimum criteria for valid indicators.

\begin{tabular}{llllllll}
\multicolumn{7}{l}{ Table 4 Descriminant } \\
\hline VAR & AVE & CR & EA & IU & RI & TR & UF \\
\hline EA & 0.73 & 0.89 & 0.85 & & & & \\
IU & 0.74 & 0.89 & 0.19 & 0.86 & & & \\
RI & 0.59 & 0.93 & 0.17 & 0.10 & 0.76 & & \\
TR & 0.58 & 0.92 & 0.06 & 0.13 & 0.47 & 0.76 & \\
UF & 0.81 & 0.93 & 0.38 & 0.09 & 0.23 & 0.10 & 0.90 \\
\hline
\end{tabular}




\section{Conclusion}

The results of this study are the validated instrument that will be used to assess the influence of "trust", "risk" and their impact on consumer behavior in the adoption of mobile commerce services. The resulting instrument has been through a validation process and fulfilling aspects to be a validated instrument. Subsequent this research will use this instrument and conduct a survey with a larger number of samples. The survey that will be done should be done online, using the help of a particular application. By conducting online surveys, it is expected to reach the distribution of questionnaires to be wider.

\section{REFERENCES}

[1] C. Baden-Fuller and S. Haefliger, "Business models and technological innovation," Long range planning, vol. 46, pp. 419-426, 2013.

[2] A. Sharma, "Trends in Internet-based business-tobusiness marketing," Industrial marketing management, vol. 31, pp. 77-84, 2002.

[3] D. W. Stewart and Q. Zhao, "Internet marketing, business models, and public policy," Journal of Public Policy \& Marketing, vol. 19, pp. 287-296, 2000.

[4] A. R. Ashraf, N. Thongpapanl, and S. Auh, "The application of the technology acceptance model under different cultural contexts: The case of online shopping adoption," Journal of International Marketing, vol. 22, pp. 68-93, 2014.

[5] K. R. Goosen, J. Wolfe, and S. C. Gold, "Panel Discussion: Alternative Ways of Using the Internet for Business Simulations to Input Decisions, Process, and Present Financial and Economic Data Output," Developments in Business Simulation and Experiential Learning, vol. 34, 2014.

[6] W. Xue, D. Li, and Y. Pei, "The Development and Current of Cross-border E-commerce," Development, 2016.

[7] P. E. Kourouthanassis and G. M. Giaglis, "Introduction to the special issue mobile commerce: the past, present, and future of mobile commerce research," International Journal of Electronic Commerce, vol. 16, pp. 5-18, 2012.

[8] C. Ruiz-Mafé, S. Sanz-Blas, and J. Aldás-Manzano, "Drivers and barriers to online airline ticket purchasing," Journal of Air Transport Management, vol. 15 , pp. 294-298, 2009.

[9] X. Luo, H. Li, J. Zhang, and J. Shim, "Examining multidimensional trust and multi-faceted risk in initial acceptance of emerging technologies: An empirical study of mobile banking services," Decision support systems, vol. 49, pp. 222-234, 2010.

[10] F. D. Davis Jr, "A technology acceptance model for empirically testing new end-user information systems: Theory and results," Massachusetts Institute of Technology, 1986.

[11] H. Hoehle and V. Venkatesh, "Mobile application usability: conceptualization and instrument development," Mis Quarterly, vol. 39, pp. 435-472, 2015.

[12] S. Kim and H. Park, "Effects of various characteristics of social commerce (s-commerce) on consumers' trust and trust performance," International Journal of Information Management, vol. 33, pp. 318-332, 2013.

[13] D. H. McKnight, V. Choudhury, and C. Kacmar, "Developing and validating trust measures for e- commerce: An integrative typology," Information systems research, vol. 13, pp. 334-359, 2002.

[14] K. Siau and Z. Shen, "Building customer trust in mobile commerce," Communications of the ACM, vol. 46, pp 91-94, 2003.

[15] Q. Yang, C. Pang, L. Liu, D. C. Yen, and J. M. Tarn, "Exploring consumer perceived risk and trust for online payments: An empirical study in China's younger generation," Computers in Human Behavior, vol. 50, pp. 9-24, 2015.

[16] A. Aljaafreh, A. Gill, and A. Al Ani, "TOWARDS THE DEVELOPMENT OF AN INITIAL TRUST MODEL FOR THE ADOPTION OF INTERNET BANKING SERVICES IN JORDAN," 2014.

[17] P. D. Chatzoglou, S. E. Kamperidou, E. Vraimaki, E. Polychrou, V. P. Aggelidis, and A. D. Diamantidis, "Factors affecting the adoption of internet banking in Greece," International Journal of Applied Systemic Studies, vol. 5, pp. 290-310, 2014.

[18] R. Dahlstrom, A. Nygaard, M. Kimasheva, and A. M. Ulvnes, "How to recover trust in the banking industry? A game theory approach to empirical analyses of bank and corporate customer relationships," International Journal of Bank Marketing, vol. 32, pp. 268-278, 2014

[19] A. Mukherjee and P. Nath, "A model of trust in online relationship banking," International Journal of Bank Marketing, vol. 21, pp. 5-15, 2003.

[20] S. K. Roy, A. Kesharwani, and S. Singh Bisht, "The impact of trust and perceived risk on internet banking adoption in India: An extension of technology acceptance model," International Journal of Bank Marketing, vol. 30, pp. 303-322, 2012.

[21] J. P. Peter and M. J. Ryan, "An investigation of perceived risk at the brand level," Journal of marketing research, pp. 184-188, 1976.

[22] M. S. Featherman and P. A. Pavlou, "Predicting eservices adoption: a perceived risk facets perspective," International journal of human-computer studies, vol. 59, pp. 451-474, 2003.

[23] M.-C. Lee, "Factors influencing the adoption of internet banking: An integration of TAM and TPB with perceived risk and perceived benefit," Electronic commerce research and applications, vol. 8, pp. 130$141,2009$.

[24] D. Gefen, "E-commerce: the role of familiarity and trust," Omega, vol. 28, pp. 725-737, 2000.

[25] K. Kim and B. Prabhakar, "Initial trust, perceived risk, and the adoption of internet banking," in Proceedings of the twenty first international conference on Information systems, 2000, pp. 537-543.

[26] S. L. Jarvenpaa, N. Tractinsky, and L. Saarinen, "Consumer trust in an internet store: a cross-cultural validation," Journal of Computer-Mediated Communication, vol. 5, pp. 0-0, 1999.

[27] J. Mou, D.-H. Shin, and J. F. Cohen, "Trust and risk in consumer acceptance of e-services," Electronic Commerce Research, pp. 1-34, 2015.

[28] W.-J. Jih, S.-Y. Wong, and T.-B. Chang, "Effects of perceived risks on adoption of Internet banking services: an empirical investigation in Taiwan," International Journal of E-Business Research (IJEBR), vol. 1, pp. 70-88, 2005.

[29] M. S. Featherman, A. D. Miyazaki, and D. E. Sprott, "Reducing online privacy risk to facilitate e-service adoption: the influence of perceived ease of use and corporate credibility," Journal of Services Marketing, vol. 24, pp. 219-229, 2010 


\section{AUTHORS}

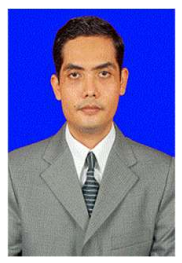

Setiawan Assegaff was born in Tanjung Karang, Indonesia. His research interesting includes Technology Adoption, E-Commerce, Knowledge Management, and Social Media. He has experiences more than twelves year as lecture at STIKOM Dinamika Bangsa. His publication has been published in national and international Journal and conferences.

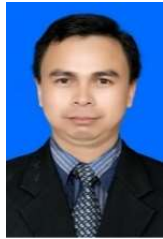

Jasmir was born in Kerinci Jambi Indonesia. His research interesting includes Artificial Intelligence, Data Mining and Big Data Social Media. He has experiences more than fifteen years as lecture at STIKOM Dinamika Bangsa. His publication has been published in National Conference and National Journal

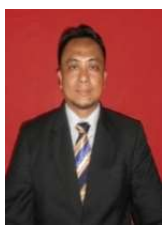

Dodo Zaenal Abidin was born in Kuningan West Java Indonesian. His research interesting includes Machine Learning, Data Mining and Big Data Social Media. He has experiences more than fifteen years as lecture at STIKOM Dinamika Bangsa. His publication has been published in National Conference and National Journal.

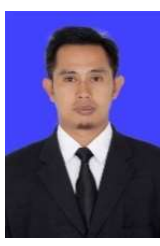

Sharipuddin was born in Lampung Indonesia. His research interesting includes Information System and Information Security. He has fifteen years of experience as a lecturer at STIKOM Dinamika Bangsa. His publications have been published in National Journal and International Conference. 